Article

\title{
Enhancement of GAD Storage Stability with Immobilization on PDA-Coated Superparamagnetic Magnetite Nanoparticles
}

\author{
Farheen Zafar ${ }^{1}$, Hong-peng Wang ${ }^{1, *}$, Chang-jiang Lv ${ }^{1}$, Muhammad-Haseeb Ullah ${ }^{1}$, \\ Chun-yan Liu ${ }^{1}$, Yu-jiao Hua ${ }^{1}$, Le-he Mei ${ }^{2}$ and Jun Huang ${ }^{1,3, *}$ \\ 1 Zhejiang Provincial Key Lab for Chemical and Biological Processing Technology of Farm Product, School of \\ Biological and Chemical Engineering, Zhejiang University of Science and Technology, Hangzhou 310023, \\ China; Farheenzafar94@outlook.com (F.Z.); yangtzelv@zju.edu.cn (C.-j.L.); \\ haseeb5aps@gmail.com (M.-H.U.); lcy2323025048@163.com (C.-y.L.); yujiaohua051209@163.com (Y.-j.H.) \\ 2 School of Biological and Chemical Engineering, Ningbo Institute of Technology, Zhejiang University, \\ Ningbo 315100, China; meilh@zju.edu.cn \\ 3 State Key Laboratory of Microbial Metabolism, Shanghai Jiao Tong University, Shanghai 200240, China \\ * Correspondence: wanghongpeng@hotmail.com (H.-p.W.); hjunlzr@163.com (J.H.); \\ Tel.: +86-570-85070393 (H.-p.W.); +86-571-85070396 (J.H.)
}

Received: 9 September 2019; Accepted: 13 November 2019; Published: 18 November 2019

\begin{abstract}
To improve the storage stability of glutamic acid decarboxylase (GAD), superparamagnetic magnetite $\left(\mathrm{Fe}_{3} \mathrm{O}_{4}\right)$ nanoparticles were synthesized by co-precipitation method and coated with polydopamine (PDA) for GAD immobilization. Dynamic light scattering and transmission electron microscopy were used to determine size of the nanoparticles, which were approximately $10 \mathrm{~nm}$, increasing to $15 \mathrm{~nm}$ after PDA-coating and to $20 \mathrm{~nm}$ upon GAD binding. Vibrational scanning measurements significantly represented the superparamagnetic behavior of the $\mathrm{Fe}_{3} \mathrm{O}_{4}$, and X-ray diffraction analysis confirmed that the crystalline structure before and after coating with PDA and the further immobilization of GAD remained the same. Thermogravimetric analysis and Fourier-transform infrared spectroscopy proved that the PDA-coating on $\mathrm{Fe}_{3} \mathrm{O}_{4}$ and further immobilization of GAD were successful. After immobilization, the enzyme can be used with a relative specific activity of $40.7 \%$ after five successive uses. The immobilized enzyme retained relative specific activity of about $50.5 \%$ after 15 days of storage at $4{ }^{\circ} \mathrm{C}$, while free enzyme showed no relative specific activity after two days of storage. The GAD immobilization on PDA-coated magnetite nanoparticles was reported for the improvement of enzyme storage stability for the first time.
\end{abstract}

Keywords: enzyme; glutamic acid decarboxylase immobilization; magnetite; nanoparticles; polydopamine

\section{Introduction}

Glutamic acid decarboxylase (GAD, EC 4.1.1.15) is required for the irreversible decarboxylation of glutamate to the non-protein nonessential amino acid gamma-aminobutyric acid (GABA) [1,2]. GABA is an inhibitory neurotransmitter [3] with pain-relieving [4], sedative [5], anti-diabetic [6], and diuretic effects [7], and has also been used as a precursor for the chemical synthesis of 2-pyrrolidone and nylon-4 [8]. While GABA can be produced both chemically and biosynthetically, GABA biosynthesis is preferred due to its mild reaction conditions and facile reaction layout $[9,10]$. Nevertheless, GABA biosynthesis is associated with its own challenges, which include separation of the product from the enzyme and lack of storage stability and reusability [11]. As such, Homaie et al. proposed enzyme immobilization to be used to overcome these challenges [12]. Park and co-workers [13] successfully 
immobilized GAD on cellulose-binding domain (CBD) for improvement in its reusability. Similarly, GAD immobilization on bacterial cellulose membranes (BCM) was performed by Yao et al. [14] for improved GABA production and reusability. Furthermore, immobilized enzymes can be separated from their reaction products by filtration and centrifugation, however these approaches tend to be difficult and time-consuming compared to methods using magnetic nanoparticles, which allow the isolation of enzymes from their products within seconds. Although magnetite nanoparticles have been extensively used for enzyme immobilization [15], such nanoparticles have a tendency to agglomerate and can be easily overcome by surface coating [16]. Polydopamine (PDA) is a polymer that has been widely used in coating surfaces [17-19]. PDA-coated magnetic nanoparticles provide many functional groups (catechol, amine, imine, and quinone) to react with a wide range of molecules, which contribute to improving covalent-linking and reducing agglomeration of magnetite nanoparticles during enzyme immobilization [20-22]. However, GAD immobilization using either bare or coated magnetic nanoparticles has not been widely implemented. GAD has typically been immobilized on carboxyl-magnetic microspheres by Li et al. [23].

In this study, magnetite nanoparticles were synthesized, coated with PDA and subsequently used for GAD immobilization. The storage stability and specific activity of GAD after immobilization, along with enzyme reusability, were measured. Taken together, our findings suggest that PDA-coated superparamagnetic nanoparticles are suitable for GAD immobilization.

\section{Results and Discussion}

\subsection{Characterization of $\mathrm{Fe}_{3} \mathrm{O}_{4}, \mathrm{Fe}_{3} \mathrm{O}_{4} / \mathrm{PDA}$ and $\mathrm{Fe}_{3} \mathrm{O}_{4} / \mathrm{PDA} / \mathrm{GAD}$ Nanoparticles}

\subsubsection{X-Ray Diffraction (XRD)}

From the X-ray diffraction (XRD) pattern (Figure 1) all samples were confirmed to be cubic in crystal structure (JCPDS file, No. 19-0629). Peaks at 2 Theta, that is $18.1^{\circ}, 30.2^{\circ}, 35.6^{\circ}, 36.2^{\circ}, 43.4^{\circ}$, $53.8^{\circ}, 57.2^{\circ}$, and $62.8^{\circ}$ correspond to the diffraction of $111,220,311,222,400,422,511$ and $440 \mathrm{of} \mathrm{Fe}_{3} \mathrm{O}_{4}$, respectively $[24,25]$. It is imperative to note that the pristine metallic structure of the nanoparticles remained crystalline.

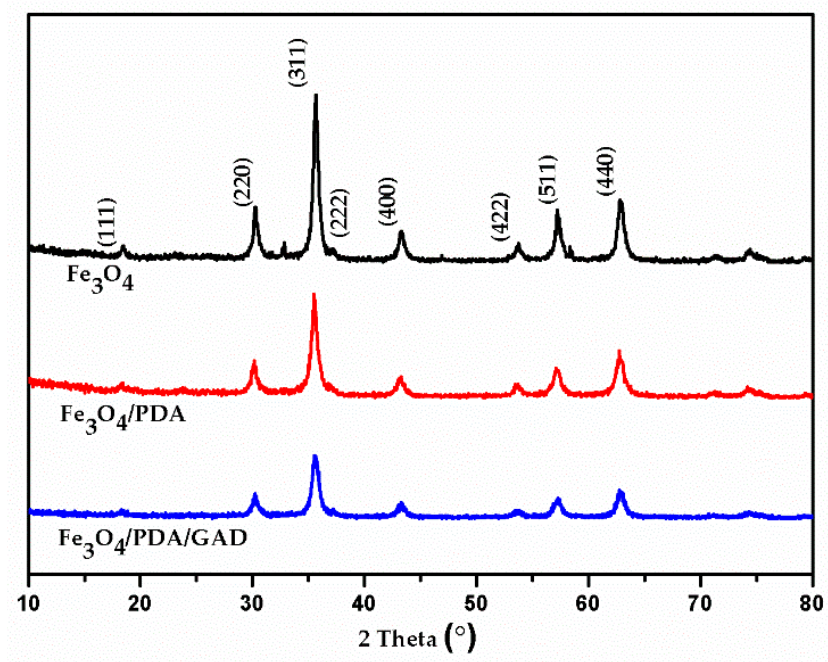

Figure 1. $\mathrm{XRD}$ pattern of $\mathrm{Fe}_{3} \mathrm{O}_{4}, \mathrm{Fe}_{3} \mathrm{O}_{4} / \mathrm{PDA}$, and $\mathrm{Fe}_{3} \mathrm{O}_{4} / \mathrm{PDA} / \mathrm{GAD}$.

\subsubsection{Vibrational Scanning Measurement (VSM)}

Vibrational scanning measurements (VSM) (Figure 2A) demonstrated that the values of remanence $\left(\mathrm{M}_{\mathrm{r}}\right)$ and coercivity $\left(\mathrm{H}_{\mathrm{c}}\right)$ were zero in all samples, indicative of superparamagnetic behavior [26]. The change in magnetic saturation from 62.9 for bare $\mathrm{Fe}_{3} \mathrm{O}_{4}$ nanoparticles to 57 for the $\mathrm{Fe}_{3} \mathrm{O}_{4} / \mathrm{PDA}$ 
condition, and 57.2 for $\mathrm{Fe}_{3} \mathrm{O}_{4} / \mathrm{PDA} / \mathrm{GAD}$, can presumably be attributed to the PDA-coating and PDA combined with immobilized GAD, respectively. Moreover, immobilized enzyme can be separated with the help of an external magnetic field within seconds (Figure 2B).
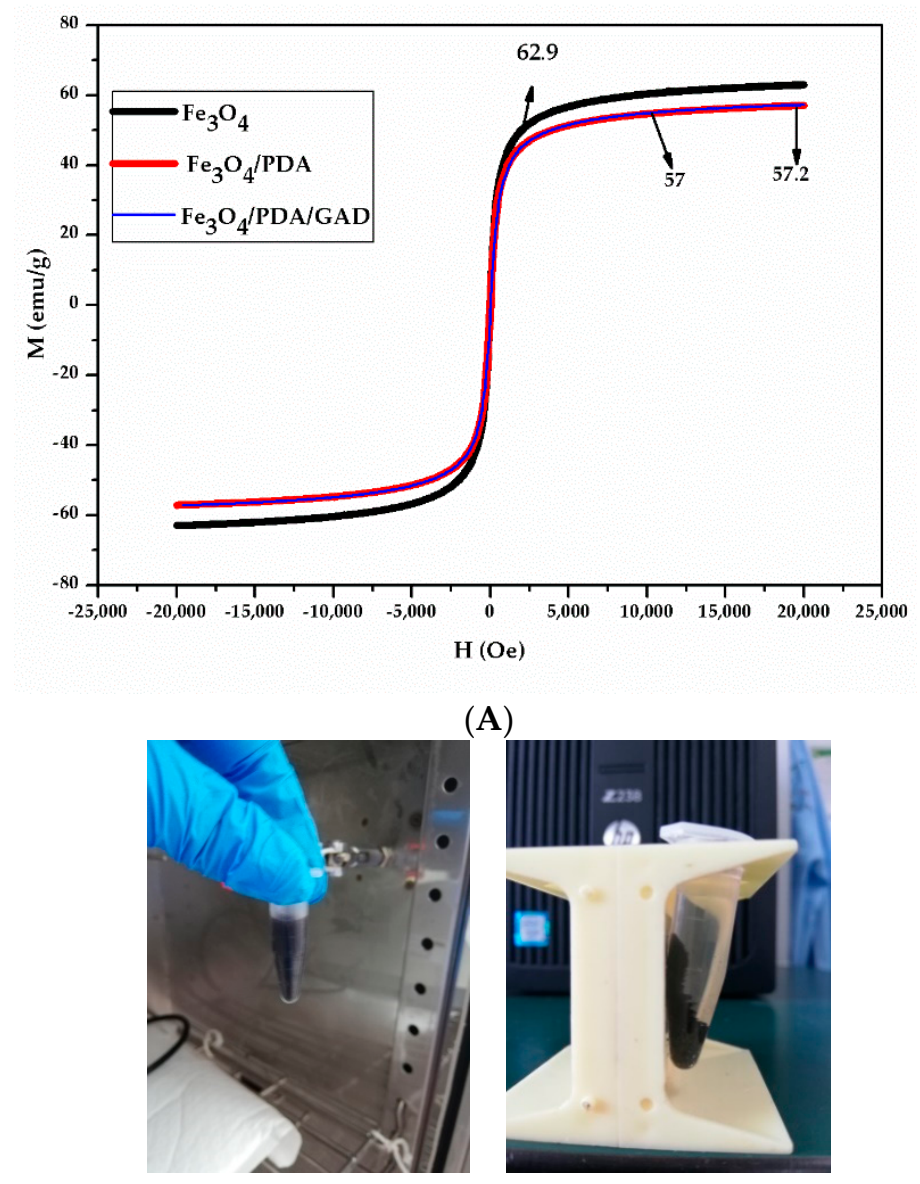

(B)

Figure 2. (A) Magnetization curve of $\mathrm{Fe}_{3} \mathrm{O}_{4}, \mathrm{Fe}_{3} \mathrm{O}_{4} / \mathrm{PDA}$, and $\mathrm{Fe}_{3} \mathrm{O}_{4} / \mathrm{PDA} / \mathrm{GAD}$ nanoparticles; (B) immobilized enzyme without and with an external magnetic field.

\subsubsection{Thermogravimetric Analysis (TGA)}

$\mathrm{Fe}_{3} \mathrm{O}_{4}, \mathrm{Fe}_{3} \mathrm{O}_{4} / \mathrm{PDA}$, and $\mathrm{Fe}_{3} \mathrm{O}_{4} / \mathrm{PDA} / \mathrm{GAD}$ samples were subjected to thermogravimetric analysis (TGA) as shown in Figure 3. The reduced weight of volatile constituents, which includes adsorbed water, was observed in the range $0-150{ }^{\circ} \mathrm{C}$ in all the three samples. $\mathrm{Fe}_{3} \mathrm{O}_{4}, \mathrm{Fe}_{3} \mathrm{O}_{4} / \mathrm{PDA}$, and $\mathrm{Fe}_{3} \mathrm{O}_{4} / \mathrm{PDA} / \mathrm{GAD}$ incurred losses of $3.4 \%, 5.8 \%$, and $3.5 \%$ in weight, respectively. Furthermore, a dramatic decrease in weight of $12.6 \%$ was observed between $150-800{ }^{\circ} \mathrm{C}$ for $\mathrm{Fe}_{3} \mathrm{O}_{4} / \mathrm{PDA}$, and was attributed to the degradation of the PDA coating [27]. For the $\mathrm{Fe}_{3} \mathrm{O}_{4} / \mathrm{PDA} / \mathrm{GAD}$ condition, the reduction in weight increased to $17.7 \%$ between $150-800{ }^{\circ} \mathrm{C}$, which may relate to the presence of immobilized GAD enzyme on the $\mathrm{Fe}_{3} \mathrm{O}_{4} / \mathrm{PDA}$ nanoparticles. The total decrease in weight for $\mathrm{Fe}_{3} \mathrm{O}_{4}, \mathrm{Fe}_{3} \mathrm{O}_{4} / \mathrm{PDA}$, and $\mathrm{Fe}_{3} \mathrm{O}_{4} / \mathrm{PDA} / \mathrm{GAD}$ was $6.9 \%, 18.4 \%$, and $21.2 \%$, respectively. The weight loss difference after PDA coating on $\mathrm{Fe}_{3} \mathrm{O}_{4}$ and $\mathrm{GAD}$ binding on $\mathrm{Fe}_{3} \mathrm{O}_{4} / \mathrm{PDA}$ was $11.5 \%$ and $2.8 \%$, respectively. 


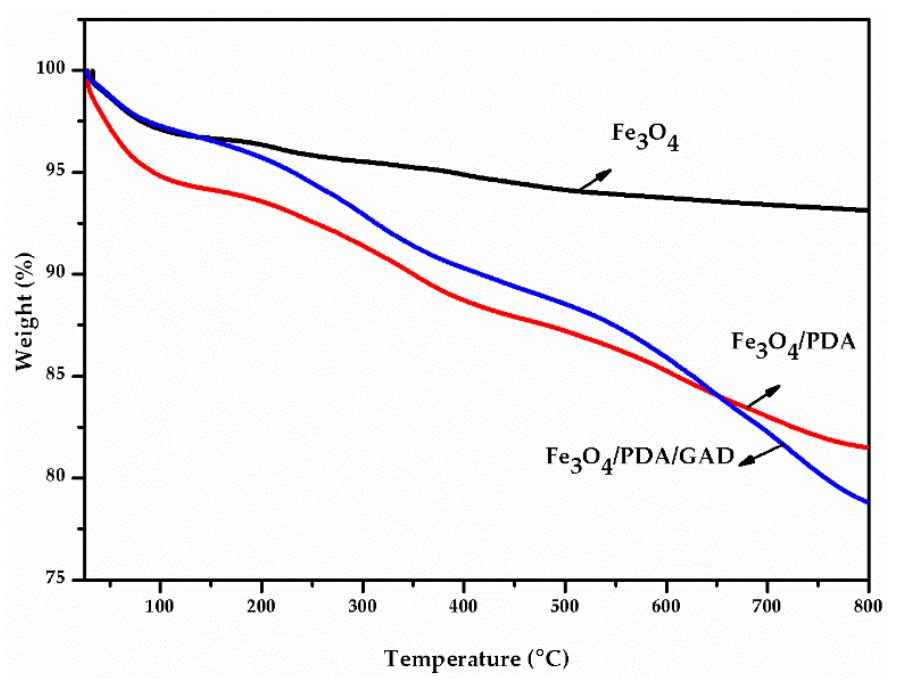

Figure 3. TGA curves of $\mathrm{Fe}_{3} \mathrm{O}_{4}, \mathrm{Fe}_{3} \mathrm{O}_{4} / \mathrm{PDA}$, and $\mathrm{Fe}_{3} \mathrm{O}_{4} / \mathrm{PDA} / \mathrm{GAD}$.

\subsubsection{Fourier-Transform Infrared Spectroscopy (FT-IR)}

Fourier-transform infrared spectroscopy (FT-IR) was used to generate a transmittance spectrum for $\mathrm{Fe}_{3} \mathrm{O}_{4}, \mathrm{Fe}_{3} \mathrm{O}_{4} / \mathrm{PDA}, \mathrm{Fe}_{3} \mathrm{O}_{4} / \mathrm{PDA} / \mathrm{GA}$, and GAD (Figure 4). Bending of the hydroxyl functional group $(\mathrm{O}-\mathrm{H})$ on the surface of the uncoated nanoparticles (labeled $\mathrm{Fe}_{3} \mathrm{O}_{4}$ ) was measured to be approximately $1634 \mathrm{~cm}^{-1}$ [28]. The band observed at $576 \mathrm{~cm}^{-1}$ and $433 \mathrm{~cm}^{-1}$ corresponds to Fe-O [29]. In the FT-IR spectrum for nanoparticles coated with PDA $\left(\mathrm{Fe}_{3} \mathrm{O}_{4} / \mathrm{PDA}\right)$, the band characteristic of PDA appears at $1286 \mathrm{~cm}^{-1}$, attributed to phenolic hydroxyl groups [30]. The band at $1634 \mathrm{~cm}^{-1}$ becomes broad due to presence of $\mathrm{C}=\mathrm{O}[31,32]$. The peak at $1485 \mathrm{~cm}^{-1}$ was associated with $\mathrm{C}=\mathrm{C}$ in aromatic rings [33], confirming the modification was successful. The appearance of new (FT-IR) bands at $1113 \mathrm{~cm}^{-1}$ and $1042 \mathrm{~cm}^{-1}$ are thought to result from the vibrational band generated by $\mathrm{C}-\mathrm{N}$ and $\mathrm{C}-\mathrm{C}$ in amino acids, respectively [34], confirming the GAD immobilization on PDA-coated nanoparticles.

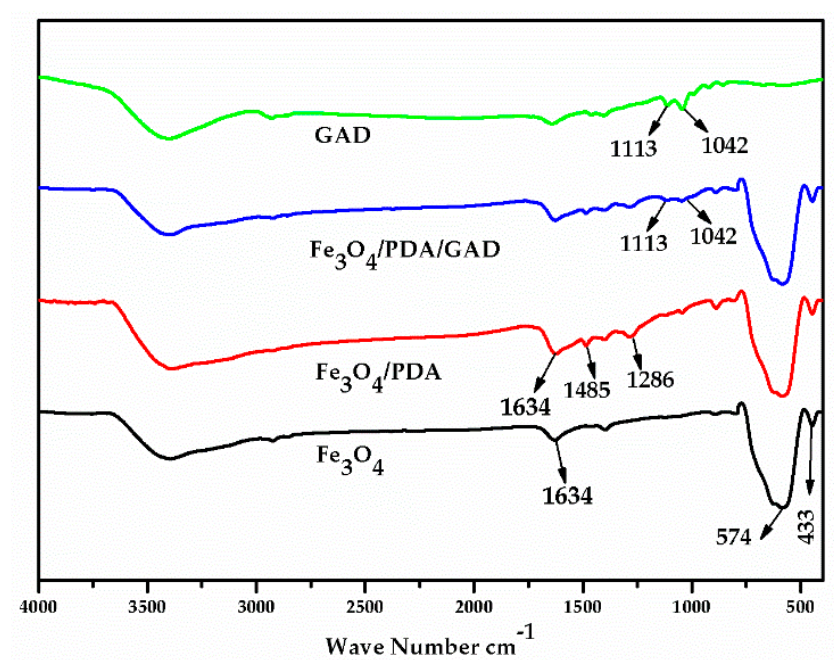

Figure 4. FT-IR transmittance spectrum of $\mathrm{Fe}_{3} \mathrm{O}_{4}, \mathrm{Fe}_{3} \mathrm{O}_{4} / \mathrm{PDA}, \mathrm{Fe}_{3} \mathrm{O}_{4} / \mathrm{PDA} / \mathrm{GAD}$, and GAD.

\subsubsection{Dynamic Light Scattering (DLS) and Transmission Electron Microscopy (TEM)}

$\mathrm{Fe}_{3} \mathrm{O}_{4}, \mathrm{Fe}_{3} \mathrm{O}_{4} / \mathrm{PDA}$, and $\mathrm{Fe}_{3} \mathrm{O}_{4} / \mathrm{PDA} / \mathrm{GAD}$ were characterized using dynamic light scattering (DLS) and transmission electron microscopy (TEM). Nanoparticle size was determined to be $10 \mathrm{~nm}$, $15 \mathrm{~nm}$, and $20 \mathrm{~nm}$, respectively (Figure 5A,B). The increase in size can be attributed to the addition of PDA-coating and subsequent GAD enzyme immobilization. 


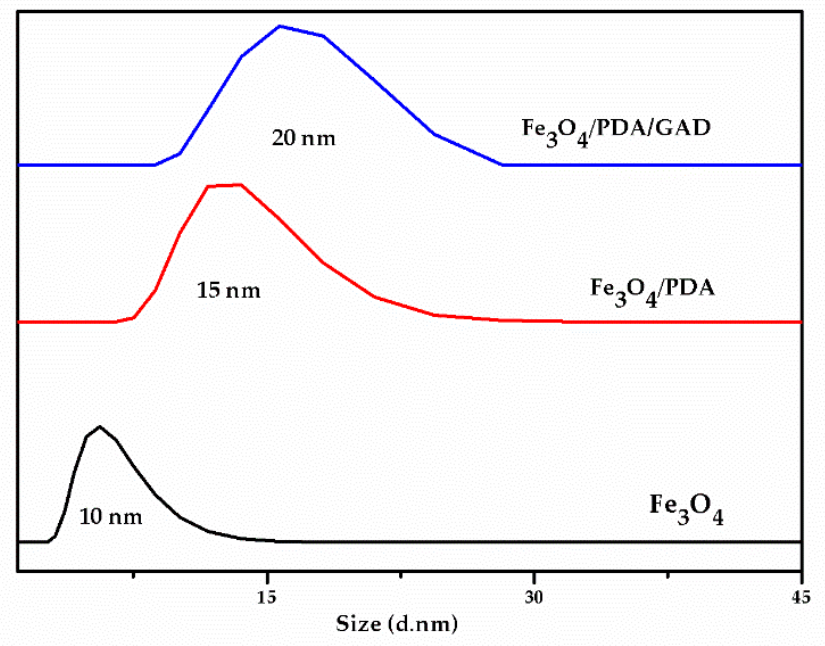

(A)
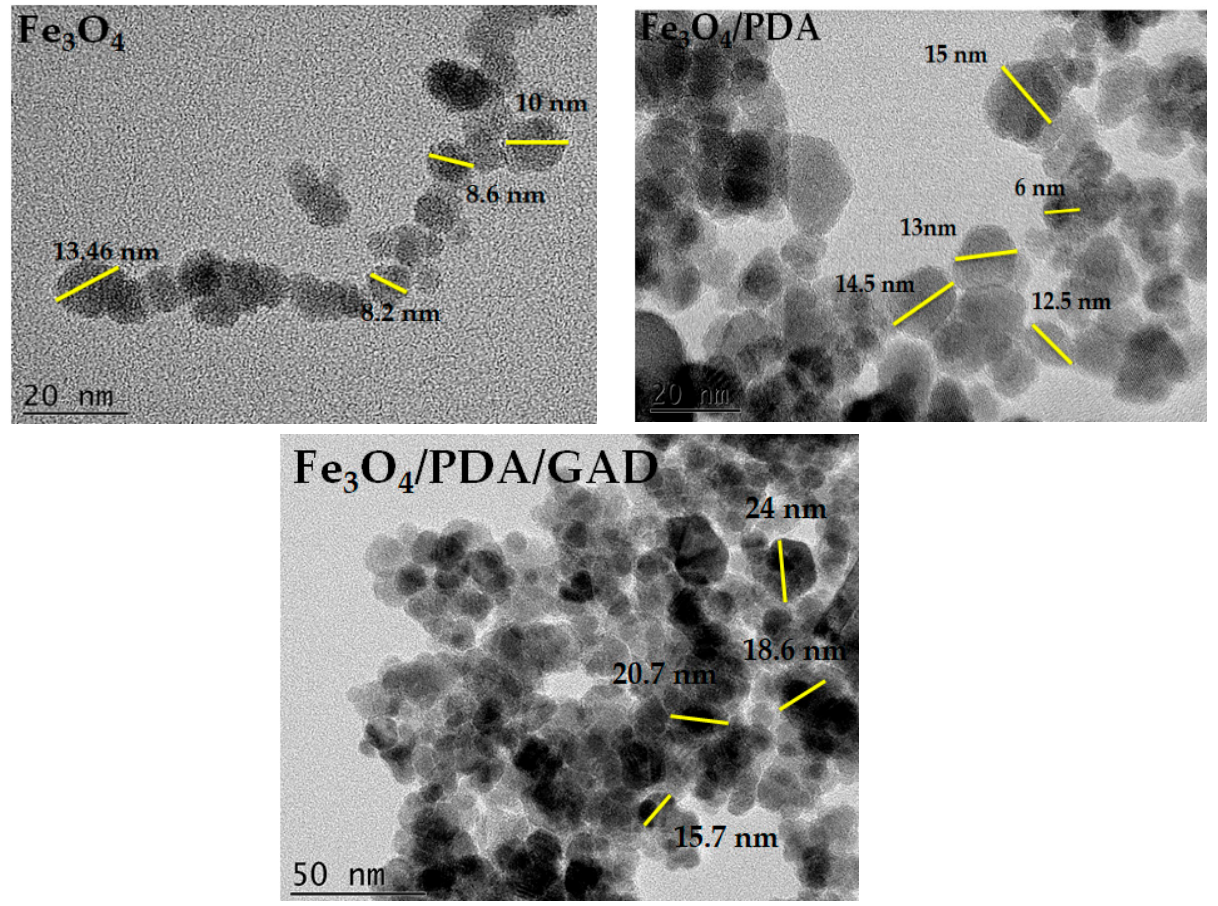

(B)

Figure 5. (A) Nanoparticle size distribution as measured by DLS for $\mathrm{Fe}_{3} \mathrm{O}_{4}, \mathrm{Fe}_{3} \mathrm{O}_{4} / \mathrm{PDA}$, and $\mathrm{Fe}_{3} \mathrm{O}_{4} / \mathrm{PDA} / \mathrm{GAD}$; (B) nanoparticle size distribution as measured by TEM images for $\mathrm{Fe}_{3} \mathrm{O}_{4}, \mathrm{Fe}_{3} \mathrm{O}_{4} / \mathrm{PDA}$, and $\mathrm{Fe}_{3} \mathrm{O}_{4} / \mathrm{PDA} / \mathrm{GAD}$.

\subsection{Study of Enzyme Activity}

\subsubsection{High Performance Liquid Chromatography (HPLC)}

All samples were analyzed with HPLC after derivatization. Dns-Cl, Dns-MSG and derivatized GABA were detected at retention times of 2.5, 7.78 and $17.8 \mathrm{~min}$, respectively. GABA produced in free enzyme is more than the immobilized enzyme and a slight difference in the derivatized MSG peaks in free and immobilized samples is also observed (Figure 6). 

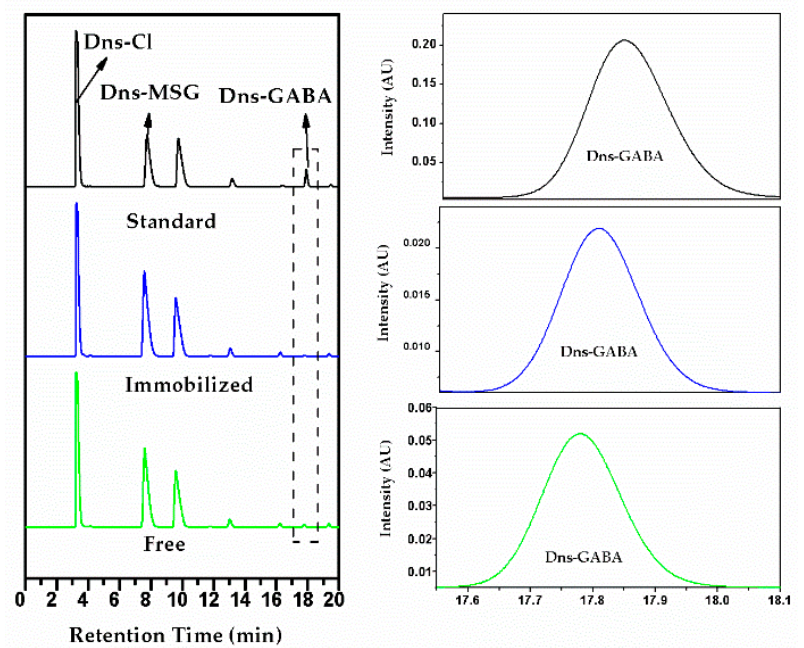

Figure 6. HPLC chromatogram for standard GABA, free and immobilized GAD with zoomed in GABA peaks.

\subsubsection{Activity of the Free and Immobilized Enzyme}

The specific activity of both free and immobilized GAD was measured, and a 3.2-fold decrease was observed after immobilization. This decrease in enzymatic activity may result from the potential structural variation of GAD and hindered enzyme-substrate interactions [35,36]. The specific activity of free and immobilized enzyme at equal concentrations $(0.085 \mathrm{mg} / \mathrm{mL})$ was determined to be $0.285 \pm$ $0.015 \mathrm{U} / \mathrm{mg}$ and $0.089 \pm 0.002 \mathrm{U} / \mathrm{mg}$, respectively.

\subsubsection{Enzyme Reusability}

The reusability of GAD immobilized on $\mathrm{Fe}_{3} \mathrm{O}_{4} / \mathrm{PDA}$ nanoparticles $\left(\mathrm{Fe}_{3} \mathrm{O}_{4} / \mathrm{PDA} / \mathrm{GAD}\right)$ was determined by comparing GAD enzymatic activity after five successive uses and expressed as a percentage of initial specific activity (referred to as relative specific activity) as shown in Figure 7. After five uses, $40.7 \%$ of initial GAD-relative specific activity was retained. Decreased GAD activity with successive uses is thought to result from a physical loss of enzyme from the nanoparticles after repeated washes, as well as potential enzyme denaturation that may occur with each cycle [37].

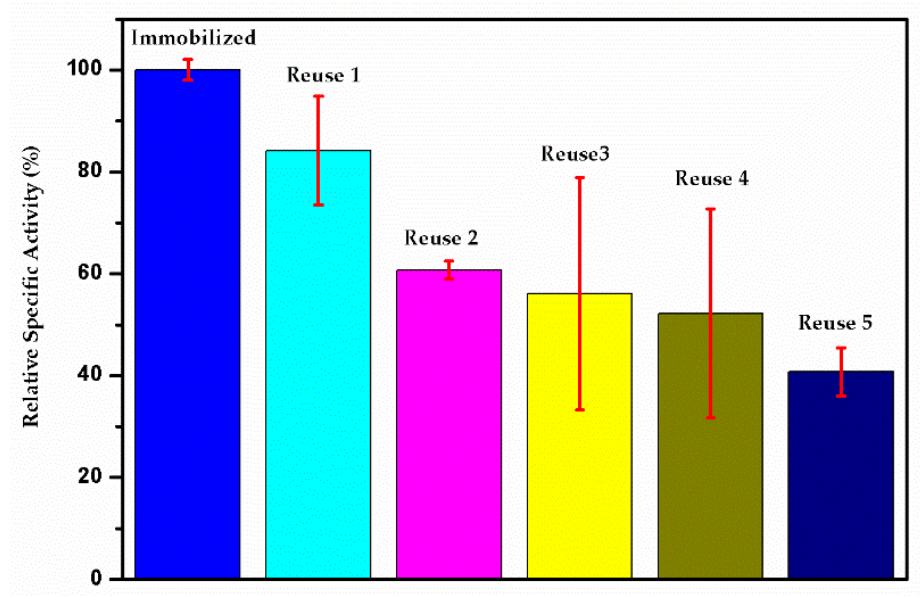

Figure 7. Reusability of immobilized GAD: relative specific activity of immobilized GAD.

\subsubsection{Storage Stability}

In order to verify this method of enzyme immobilization to be more practical than others, improvement in storage stability is required. The relative specific activity retained by free GAD enzyme 
on the second day was $17 \%$, with no specific activity observed on the third day, while immobilized enzyme retained $50.5 \%$ after 15 days (Figure 8), respectively. Protein concentration analysis was performed before each measurement of storage stability, and it demonstrated that enzyme leaching from the nanoparticle support was negligible. These data demonstrate that the GAD was strongly cross-linked on PDA-coated superparamagnetic magnetite nanoparticles [38].

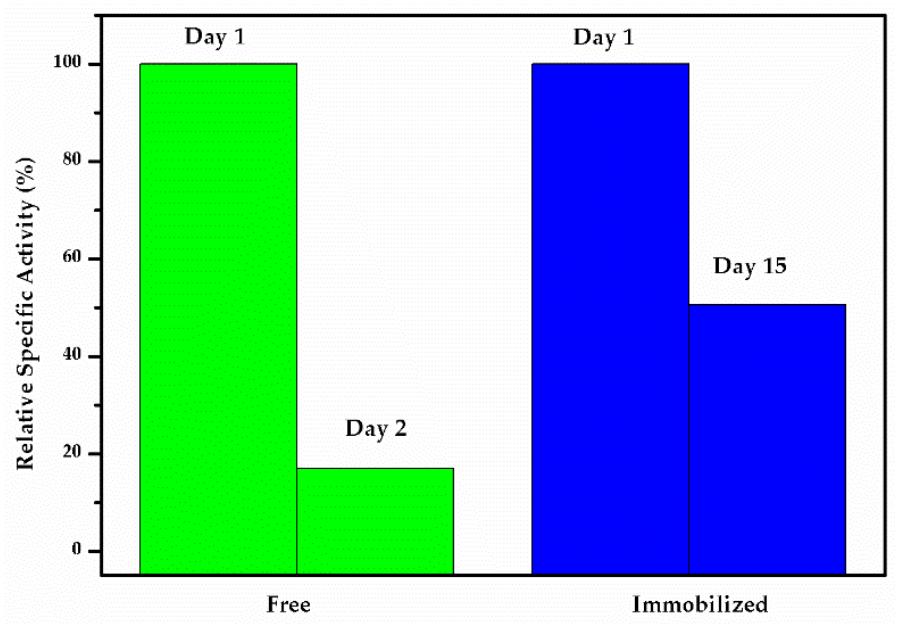

Figure 8. Storage stability: relative specific activity of free GAD on first two days and of immobilized GAD on 1 st and 15 th day.

\section{Materials and Methods}

\subsection{Materials}

Ferric chloride $\left(\mathrm{FeCl}_{3} \cdot 6 \mathrm{H}_{2} \mathrm{O}\right)$, ferrous chloride $\left(\mathrm{FeCl}_{2} \cdot 4 \mathrm{H}_{2} \mathrm{O}\right)$ was obtained from Sigma Aldrich Co., Ltd. (Shanghai, China), and ammonia solution $\left(\mathrm{NH}_{3} \cdot \mathrm{H}_{2} \mathrm{O}\right)$, dopamine hydrochloride, glutaraldehyde, tetrahydrofuran, and ethanol were purchased from Shanghai Wokai Biotechnology Co., Ltd. (Shanghai, China). Pyridoxal 5'-phosphate (PLP), kanamycin, isopropyl $\beta$-D-1-thiogalactopyranoside (IPTG), Coomassie blue, monosodium glutamate (L-MSG), gamma-aminobutyric acid (GABA) and dansyl chloride (Dns-Cl) were obtained from BBI Life Sciences Co., Ltd. (Shanghai, China). Affinity chromatography resin (Ni-NTA Sefinose ${ }^{\mathrm{TM}}$ Resin), sodium acetate, and sodium chloride were bought from Sangon Biotech Co., Ltd. (Shanghai, China). Water (Milli Q) was produced in our own lab, methanol (HPLC grade), Tryptone and yeast extract were purchased from Thermo Fischer Scientific Co., Ltd. (Shanghai, China).

\section{Bacterial Culture}

The E. coli BL21 (DE3) strain harboring GAD mutant T383K (pET28a-gad) was used for recombinant GAD production. Bacterial cultures were grown aerobically in Luria-Bertani (LB) broth containing $25 \mu \mathrm{g} / \mathrm{mL}$ kanamycin with constant shaking $(250 \mathrm{rpm})$ at $37^{\circ} \mathrm{C}$. Solid medium for plating was prepared by adding $1.5 \%$ agar to the appropriate volumes of LB medium containing $10 \mathrm{~g} / \mathrm{L}$ tryptone, $5 \mathrm{~g} / \mathrm{L}$ yeast extract, and $10 \mathrm{~g} / \mathrm{L}$ sodium chloride.

\subsection{Magnetite $\left(\mathrm{Fe}_{3} \mathrm{O}_{4}\right)$ Nanoparticle Synthesis}

Magnetite nanoparticles were synthesized as reported previously [39]. $\mathrm{FeCl}_{3} \cdot 6 \mathrm{H}_{2} \mathrm{O}(25.4 \mathrm{~g})$ and $\mathrm{FeCl}_{2} \cdot 4 \mathrm{H}_{2} \mathrm{O}(9.3 \mathrm{~g})$ were dissolved in $250 \mathrm{~mL}$ of deionized water. Then, $50 \mathrm{~mL}$ of $29 \%$ by wt. ammonia solution was added drop-wise with continuous stirring at $350 \mathrm{rpm}, 80^{\circ} \mathrm{C}$. When black precipitates formed, the mixture was stirred for an additional $30 \mathrm{~min}$ at $350 \mathrm{rpm}$, at $70^{\circ} \mathrm{C}$, and then cooled to $25^{\circ} \mathrm{C}$. The reaction was performed under argon gas protection. Nanoparticles were pelleted with an external 
magnetic field and washed three to five times with deionized water and ethanol, then dried overnight in a vacuum oven at $60^{\circ} \mathrm{C}$.

\subsection{Polydopamine Coating of Magnetite Nanoparticles ( $\mathrm{Fe}_{3} \mathrm{O}_{4} / \mathrm{PDA}$ )}

Magnetite $\left(\mathrm{Fe}_{3} \mathrm{O}_{4}\right)$ nanoparticles were coated with PDA according to previously reported methods with some modifications [40]. Briefly, $20 \mathrm{~g}$ of dopamine hydrochloride was dissolved in $450 \mathrm{~mL}$ of Tris- $\mathrm{HCl}\left(100 \mathrm{mM}, \mathrm{pH}\right.$ 8.5). The solution was then added to the $\mathrm{Fe}_{3} \mathrm{O}_{4}$ nanoparticles (10 g). The mixture was stirred mechanically at $300 \mathrm{rpm}, 60^{\circ} \mathrm{C}$ for $5 \mathrm{~h}$. The product was then separated using a magnetic field, and nanoparticles were washed with distilled water three times before being dried overnight at $40^{\circ} \mathrm{C}$.

\subsection{Enzyme Expression and Purification}

Enzymatic fermentation was carried out as previously reported with minor alterations [41]. $E$. coli BL21 (DE3)/pET28a-gad cultures were inoculated in 5 mL LB medium supplemented with 50 $\mu \mathrm{g} / \mathrm{mL}$ kanamycin and incubated at $37^{\circ} \mathrm{C}$ overnight with shaking $(180 \mathrm{rpm})$. When the $\mathrm{OD}_{600}$ reached 0.8 , cultures were expanded for $2 \mathrm{~h}$ in $200 \mathrm{~mL}$ of LB under the same conditions. Once the $\mathrm{OD}_{600}$ of these expanded cultures reached 0.7, IPTG was added to a final concentration of $0.5 \mathrm{mM}$ and cultures were incubated at $25^{\circ} \mathrm{C}$ overnight with shaking $(150 \mathrm{rpm})$. Cells were harvested by centrifugation at $8000 \mathrm{rpm}$ for $10 \mathrm{~min}$ and washed three times with $50 \mathrm{mM}$ PBS. Cells were then lysed by sonication, and cell extracts were centrifuged at $12,000 \mathrm{rpm}$ at $4{ }^{\circ} \mathrm{C}$ for $30 \mathrm{~min}$ to remove cell debris. Recombinant proteins were purified to apparent homogeneity by Ni-affinity chromatography according to the manufacturer's instructions.

\subsection{Enzyme Immobilization}

GAD was immobilized on PDA-coated magnetite nanoparticles according to methods described by Peng et al. with minor modifications [42]. $\mathrm{Fe}_{3} \mathrm{O}_{4} / \mathrm{PDA}(2 \mathrm{mg})$ nanoparticles were activated by dispersion in $40 \mu \mathrm{L}$ PBS $(10 \mathrm{mM}, \mathrm{pH} 7)$ with glutaraldehyde $(0.16 \mu \mathrm{L}, 50 \%$ by wt.). Activated nanoparticles were washed with PBS buffer three times. A total of $20 \mu \mathrm{L}$ of GAD enzyme $(0.085 \mathrm{mg} / \mathrm{mL})$ was immobilized by sonication for $20 \mathrm{~min}$, washed with PBS buffer twice, separated with a magnetic field, and stored in the same buffer at $4{ }^{\circ} \mathrm{C}$ for further use.

\subsection{Characterization of GAD Immobilized on PDA-Coated $\mathrm{Fe}_{3} \mathrm{O}_{4}$ Nanoparticles $\left(\mathrm{Fe}_{3} \mathrm{O}_{4} / \mathrm{PDA} / \mathrm{GAD}\right)$}

Fourier-transform infrared (FT-IR) transmittance bands were investigated with a spectrophotometer (Vertex 70, Brucker Optik GmbH, Karlsruhe, Germany) in the range of $400-4000 \mathrm{~cm}^{-1}$. The crystal structure was determined using an X-ray diffractometer (XRD) (Rigaku, RINT2000, Tokyo, Japan), $\mathrm{CuK} \alpha$ radiation $(\lambda=1.54 \AA)$, and was scanned within a range of $10-80^{\circ}$ at a rate of $5^{\circ} / \mathrm{min}$ at $20 \mathrm{~mA}$ and $40 \mathrm{kV}$. The morphologies and sizes of $\mathrm{Fe}_{3} \mathrm{O}_{4}, \mathrm{Fe}_{3} \mathrm{O}_{4} / \mathrm{PDA}$, and $\mathrm{Fe}_{3} \mathrm{O}_{4} / \mathrm{PDA} / \mathrm{GAD}$ nanoparticles were characterized using transmission electron microscopy (TEM) (JEOL JEM-2100, Tokyo, Japan). The size of $\mathrm{Fe}_{3} \mathrm{O}_{4}, \mathrm{Fe}_{3} \mathrm{O}_{4} / \mathrm{PDA}$, and $\mathrm{Fe}_{3} \mathrm{O}_{4} / \mathrm{PDA} / \mathrm{GAD}$ nanoparticles was quantified by dynamic light scattering (DLS) (Malvern Zetasizer Nano ZS particle analyzer, ZEN3600, Malvern, UK). Thermogravimetric analysis (TGA) was conducted by using a STA 449 F3 DSC/DTA-TG analyzer (Netzsch Germany, Wunsiedel, Germany) under an inert nitrogen atmosphere in the temperature range of $25-800{ }^{\circ} \mathrm{C}$ at a heating rate of $10^{\circ} \mathrm{C} / \mathrm{min}$. The magnetic properties of each condition were measured using a vibrating sample magnometer (PPMS-9, Quantum Design, San Diego, USA) Protein concentration was measured by Bradford assay using a 96 well-plate spectrophotometer (spectramax 190, serial number NNR 07134, Thermo Fischer Scientific Co., Ltd. (Shanghai, China) and enzyme activity was analyzed by the HPLC system comprised of a Waters Alliance with e2695 separation module and Photodiode array 2998 at a wavelength of $254 \mathrm{~nm}$. 


\subsection{GAD Activity Assay}

The concentration of free and immobilized GAD was determined by Bradford assay at $595 \mathrm{~nm}$ using a 96-well plate spectrophotometer [43]. The enzymatic activity of free and immobilized GAD was tested in triplicate using a modified version of a previously described method [44]. Briefly, free enzyme $(20 \mu \mathrm{L})$ and immobilized enzyme $(1.7 \mu \mathrm{g})$ were mixed with $420 \mu \mathrm{L}$ of substrate $(100 \mathrm{mM} \mathrm{L}-\mathrm{MSG}, 0.2 \mathrm{M}$ sodium acetate buffer, and $0.01 \mathrm{M} \mathrm{PLP})$ at $\mathrm{pH} 4.8$ in a $1.5 \mathrm{~mL}$ tube. The mixture was incubated in a thermomixer at $1000 \mathrm{rpm}, 37^{\circ} \mathrm{C}$ for $15 \mathrm{~min}$. After separation with an external magnetic field, $0.1 \mathrm{~mL}$ of supernatant was added to $0.9 \mathrm{~mL}$ of sodium bicarbonate $(0.2 \mathrm{M}, \mathrm{pH} 9.8)$. Subsequently, $0.5 \mathrm{~mL}$ of the sample and $0.5 \mathrm{~mL}$ dansyl chloride (Dns-Cl, $8 \mathrm{~g} / \mathrm{L}$ ) were mixed and incubated in a thermomixer at $400 \mathrm{rpm}, 40^{\circ} \mathrm{C}$ for $60 \mathrm{~min}$ in a dark environment. The derivative samples were measured using HPLC for the detection and quantification of GABA. One unit (U) of GAD activity was defined as the amount of GAD enzyme that produced $1 \mu \mathrm{mol}$ of GABA in $1 \mathrm{sec}$ under the above conditions, and specific activity was defined in $\mathrm{U} / \mathrm{mg}$.

\subsection{High Performance Liquid Chromatography (HPLC) Analysis and Conditions}

Methanol (A) and sodium acetate buffer with tetrahydrofuran $(10 \mathrm{~mL} / \mathrm{L})$ and methanol $(150 \mathrm{~mL} / \mathrm{L})$ (B) were used as mobile phases. The derivative samples were separated on a column (Hypersil ODS-2, particle size $5 \mu \mathrm{m}, 4.6 \times 250 \mathrm{~mm}$ ) with a flow rate of $1 \mathrm{~mL} / \mathrm{min}$ for $30 \mathrm{~min}$ at $25 \pm 5^{\circ} \mathrm{C}$ with a gradient elution program as outlined in Table 1.

Table 1. GABA separation method used for liquid chromatography.

\begin{tabular}{cccc}
\hline Time (min) & Flow Rate (mL/min) & $\mathbf{A} \%$ & $\mathbf{B} \%$ \\
\hline 0 & 1 & 20 & 80 \\
5 & 1 & 20 & 80 \\
20 & 1 & 50 & 50 \\
21 & 1 & 100 & 0 \\
27 & 1 & 100 & 0 \\
28 & 1 & 20 & 80 \\
30 & 1 & 20 & 80 \\
\hline
\end{tabular}

\subsection{Reusability Assay}

The reusability of immobilized GAD enzyme was tested five times in triplicate, with an equal amount of substrate as described in Section 3.7. After each measurement, the immobilized enzyme was washed with sodium acetate buffer ( $\mathrm{pH}$ 4.8) three times, and then separated by a magnetic field, and enzyme activity was measured using HPLC.

\subsection{Storage Stability}

The storage stability of the free enzyme was evaluated at an interval of 1 day over 3 days, while immobilized GAD storage stability was tested on the 1st day and on the 15th day. The immobilized enzyme was measured for activity (without testing for reusability) and stored in storing buffer $(10 \mathrm{mM}$ PBS, pH 7) at $4{ }^{\circ} \mathrm{C}$. To measure enzyme storage stability, GAD was isolated from the storing buffer using a magnetic field. Enzymatic activity was then measured and the storing buffer was analyzed for enzyme leaching by Bradford assay, in parallel.

\section{Conclusions}

Magnetite $\left(\mathrm{Fe}_{3} \mathrm{O}_{4}\right)$ nanoparticles were synthesized according to previously described methods and subsequently coated with PDA. We describe herein, for the first time, the use of PDA-coated $\mathrm{Fe}_{3} \mathrm{O}_{4}$ nanoparticles for the immobilization of GAD. Our results demonstrated that the superparamagnetism of $\mathrm{Fe}_{3} \mathrm{O}_{4}$ nanoparticles was maintained after PDA-coating and GAD enzyme immobilization. The results 
also showed that the specific activity of the GAD enzyme was decreased by 3.2-fold when compared to that of free enzyme. Furthermore, we demonstrated that immobilized GAD can be used up to five times and still retain $40.7 \%$ of its relative specific activity. When stored at $4{ }^{\circ} \mathrm{C}, 50.5 \%$ of GAD relative specific activity was maintained for up to 15 days, an intense improvement over the free enzyme, which loses its activity after only two days of storage. This improvement in GAD storage stability will allow for the applications of this enzyme to be expanded within the pharmaceutical, chemical, and food industries. Furthermore, our results demonstrate the advantages of enzyme immobilization in general, and might encourage others to apply this approach to other unstable enzymes, such as transaminases, to enhance their application in such industries.

Author Contributions: The conceptualization and methodology, H.-p.W. and J.H.; Validation M.-H.U.; investigation of analytical methods used, C.-y.L. and Y.-j.H.; data curation, C.-j.L. and L.-h.M.; formal analysis and writing-original draft preparation F.Z.

Funding: We are grateful to the National Natural Science Foundation of China (Nos. 31,470,793 and 31670804), Zhejiang Natural Science Foundation (Nos.LY16B060008, and LQ18B060002), key projects at the central government level: the ability establishment of sustainable use for valuable Chinese medicine resources (2060302), and the foundation of State Key Laboratory of Microbial Metabolism (MMLKF19-10).

Acknowledgments: The authors would like to thank Shun-Li Kou and Yuan-Zhi Yu for their support in characterizing the samples and also to the anonymous reviewers for their insightful suggestions.

Conflicts of Interest: There are no conflicts of interests.

\section{References}

1. Lin, Q.; Yang, S.; Lü, F.; Lu, Z.; Bie, X.; Jiao, Y.; Zou, X. Cloning and expression of glutamate decarboxylase gene from streptococcus thermophilus y2. J. Gen. Appl. Microbiol. 2009, 55, 305-310. [CrossRef]

2. Yu, K.; Lin, L.; Hu, S.; Huang, J.; Mei, L. C-terminal truncation of glutamate decarboxylase from lactobacillus brevis cgmcc 1306 extends its activity toward near-neutral pH. Enzyme Microb. Technol. 2012, 50, $263-269$. [CrossRef]

3. Lin, L.; Hu, S.; Yu, K.; Huang, J.; Yao, S.; Lei, Y.; Hu, G.; Mei, L. Enhancing the activity of glutamate decarboxylase from lactobacillus brevis by directed evolution. Chin. J. Chem. Eng. 2014, 22, 1322-1327. [CrossRef]

4. Enna, S.; McCarson, K.E. The role of GABA in the mediation and perception of pain. Adv. Pharmacol. 2006, 54, 1-27. [PubMed]

5. Nelson, L.; Guo, T.; Lu, J.; Saper, C.; Franks, N.; Maze, M. The sedative component of anesthesia is mediated by GABA a receptors in an endogenous sleep pathway. Nat. Neurosci. 2002, 5, 979. [CrossRef] [PubMed]

6. Soltani, N.; Qiu, H.; Aleksic, M.; Glinka, Y.; Zhao, F.; Liu, R.; Li, Y.; Zhang, N.; Chakrabarti, R.; Ng, T. GABA exerts protective and regenerative effects on islet beta cells and reverses diabetes. Proc. Natl. Acad. Sci. USA 2011, 108, 11692-11697. [CrossRef] [PubMed]

7. Hiraga, K.; Ueno, Y.; Oda, K. Glutamate decarboxylase from lactobacillus brevis: Activation by ammonium sulfate. Biosci. Biotechnol. Biochem. 2008, 72, 1299-1306. [CrossRef]

8. Park, S.J.; Kim, E.Y.; Noh, W.; Oh, Y.H.; Kim, H.Y.; Song, B.K.; Cho, K.M.; Hong, S.H.; Lee, S.H.; Jegal, J. Synthesis of nylon 4 from gamma-aminobutyrate (GABA) produced by recombinant escherichia coli. Bioprocess Biosyst. Eng. 2013, 36, 885-892. [CrossRef]

9. Choi, S.-I.; Lee, J.-W.; Park, S.-M.; Lee, M.-Y.; Ji, G.-E.; Park, M.-S.; Heo, T.-R. Improvement of gamma-aminobutyric acid (GABA) production using cell entrapment of lactobacillus brevis GABA 057. J. Microbiol. Biotechnol. 2006, 16, 562-568.

10. Huang, J.; Mei, L.; Wu, H.; Lin, D. Biosynthesis of $\gamma$-aminobutyric acid (GABA) using immobilized whole cells of lactobacillus brevis. World J. Microbiol. Biotechnol. 2007, 23, 865-871. [CrossRef]

11. Xu, N.; Wei, L.; Liu, J. Biotechnological advances and perspectives of gamma-aminobutyric acid production. World J. Microbiol. Biotechnol. 2017, 33, 64. [CrossRef] [PubMed]

12. Homaei, A.A.; Sariri, R.; Vianello, F.; Stevanato, R. Enzyme immobilization: An update. J. Chem. Biol. 2013, 6, 185-205. [CrossRef] [PubMed] 
13. Park, H.; Ahn, J.; Lee, J.; Lee, H.; Kim, C.; Jung, J.-K.; Lee, H.; Lee, E.G. Expression, immobilization and enzymatic properties of glutamate decarboxylase fused to a cellulose-binding domain. Int. J. Mol. Sci. 2012, 13, 358-368. [CrossRef] [PubMed]

14. Yao, W.; Wu, X.; Zhu, J.; Sun, B.; Miller, C. In vitro enzymatic conversion of $\gamma$-aminobutyric acid immobilization of glutamate decarboxylase with bacterial cellulose membrane (BCM) and non-linear model establishment. Enzyme Microb. Technol. 2013, 52, 258-264. [CrossRef] [PubMed]

15. Khoshnevisan, K.; Poorakbar, E.; Baharifar, H.; Barkhi, M. Recent advances of cellulase immobilization onto magnetic nanoparticles: An update review. Magnetochemistry 2019, 5, 36. [CrossRef]

16. Mascolo, M.; Pei, Y.; Ring, T. Room temperature co-precipitation synthesis of magnetite nanoparticles in a large $\mathrm{pH}$ window with different bases. Materials 2013, 6, 5549-5567. [CrossRef]

17. Lee, H.; Rho, J.; Messersmith, P.B. Facile conjugation of biomolecules onto surfaces via mussel adhesive protein inspired coatings. Adv. Mater. 2009, 21, 431-434. [CrossRef]

18. Jiang, J.-H.; Zhu, L.-P.; Li, X.-L.; Xu, Y.-Y.; Zhu, B.-K. Surface modification of pe porous membranes based on the strong adhesion of polydopamine and covalent immobilization of heparin. J. Membr. Sci. 2010, 364, 194-202. [CrossRef]

19. Timin, A.S.; Solomonov, A.V.; Musabirov, I.I.; Sergeev, S.N.; Ivanov, S.P.; Rumyantsev, E.V.; Goncharenko, A. Immobilization of bovine serum albumin onto porous poly(vinylpyrrolidone)-modified silicas. Ind. Eng. Chem. Res. 2014, 53, 13699-13710. [CrossRef]

20. Martín, M.; Salazar, P.; Jiménez, C.; Lecuona, M.; Ramos, M.J.; Ode, J.; Alcoba, J.; Roche, R.; Villalonga, R.; Campuzano, S. Rapid legionella pneumophila determination based on a disposable core-shell $\mathrm{Fe}_{3} \mathrm{O}_{4} @$ polydopamine magnetic nanoparticles immunoplatform. Anal. Chim. Acta 2015, 887, 51-58. [CrossRef]

21. Ding, Y.; Floren, M.; Tan, W. Mussel-inspired polydopamine for bio-surface functionalization. Biosurf. Biotribol. 2016, 2, 121-136. [CrossRef] [PubMed]

22. Park, J.; Brust, T.F.; Lee, H.J.; Lee, S.C.; Watts, V.J.; Yeo, Y. Polydopamine-based simple and versatile surface modification of polymeric nano drug carriers. ACS Nano 2014, 8, 3347-3356. [CrossRef] [PubMed]

23. Li, J.; Xie, T.; Hu, S.; Xie, D.; Fang, H.; Mei, L.; Huang, J.; Wang, J.; Yao, S. Immobilized glutamate decarboxylase by carboxal magnetic microspheres. J. Chem. Ind. Eng. 2016, 68, 1550-1557.

24. Veisi, H.; Parvizi, F.; Abdi, M.R. Magnetic solid-phase extraction and uv/vis spectrophotometric determination of trace amount of copper in vegetable and fruit samples after preconcentration of its pentetate complex. J. Nanoanal. 2018, 5, 171-181.

25. Yu, B.Y.; Kwak, S.-Y. Assembly of magnetite nanocrystals into spherical mesoporous aggregates with a 3-d wormhole-like pore structure. J. Mater.Chem. 2010, 20, 8320. [CrossRef]

26. Khalil, M.I. Co-precipitation in aqueous solution synthesis of magnetite nanoparticles using iron(III) salts as precursors. Arab. J. Chem. 2015, 8, 279-284. [CrossRef]

27. Oroujeni, M.; Kaboudin, B.; Xia, W.; Jönsson, P.; Ossipov, D.A. Conjugation of cyclodextrin to magnetic Zn nanoparticles via polydopamine coating for drug delivery. Prog. Org. Coat. 2018, 114, 154-161. [CrossRef]

28. Nalbandian, L.; Patrikiadou, E.; Zaspalis, V.; Patrikidou, A.; Hatzidaki, E.; Papandreou, C.N. Magnetic nanoparticles in medical diagnostic applications: Synthesis, characterization and proteins conjugation. Curr. Nanosci. 2016, 12, 455-468. [CrossRef]

29. Veisi, H.; Pirhayati, M.; Kakanejadifard, A.; Mohammadi, P.; Abdi, M.R.; Gholami, J.; Hemmati, S. In situ green synthesis of $\mathrm{Pd}$ nanoparticles on tannic acid-modified magnetite nanoparticles as a green reductant and stabilizer agent: Its application as a recyclable nanocatalyst $\left(\mathrm{Fe}_{3} \mathrm{O}_{4} @ \mathrm{Ta} / \mathrm{Pd}\right)$ for reduction of 4-nitrophenol and suzuki reactions. ChemistrySelect 2018, 3, 1820-1826. [CrossRef]

30. An, P.; Zuo, F.; Li, X.; Wu, Y.; Zhang, J.; Zheng, Z.; Ding, X.; Peng, Y. A bio-inspired polydopamine approach to preparation of gold-coated $\mathrm{Fe}_{3} \mathrm{O}_{4}$ core-shell nanoparticles: Synthesis, characterization and mechanism. Nano 2013, 8, 1350061. [CrossRef]

31. Luo, H.; Gu, C.; Zheng, W.; Dai, F.; Wang, X.; Zheng, Z. Facile synthesis of novel size-controlled antibacterial hybrid spheres using silver nanoparticles loaded with polydopamine spheres. RSC Adv. 2015, 5, 13470-13477. [CrossRef]

32. Suárez-García, S.; Sedó, J.; Saiz-Poseu, J.; Ruiz-Molina, D. Copolymerization of a catechol and a diamine as a versatile polydopamine-like platform for surface functionalization: The case of a hydrophobic coating. Biomimetics 2017, 2, 22. [CrossRef] [PubMed] 
33. Yang, Y.; Wang, S.; Zhou, Z.; Zhang, R.; Shen, H.; Song, J.; Su, P.; Yang, Y. Enhanced reusability and activity: DNA directed immobilization of enzyme on polydopamine modified magnetic nanoparticles. Biochem. Eng. J. 2018, 137, 108-115. [CrossRef]

34. Barth, A. The infrared absorption of amino acid side chains. Prog. Biophys. Mol. Biol. 2000, 74, 141-173. [CrossRef]

35. Chapman, J.; Ismail, A.E.; Dinu, C.Z. Industrial applications of enzymes: Recent advances, techniques, and outlooks. Catalysts 2018, 8, 238. [CrossRef]

36. Zhang, D.-H.; Yuwen, L.-X.; Peng, L.-J. Parameters affecting the performance of immobilized enzyme. J. Chem. 2013, 2013, 946248. [CrossRef]

37. Sharma, M.; Sharma, V.; Majumdar, D.K. Entrapment of alpha-amylase in agar beads for biocatalysis of macromolecular substrate. Int. Sch. Res. Notices 2014, 2014, 936129.

38. Konwarh, R.; Karak, N.; Rai, S.K.; Mukherjee, A.K. Polymer-assisted iron oxide magnetic nanoparticle immobilized keratinase. Nanotechnology 2009, 20, 225107. [CrossRef]

39. Dolgormaa, A.; Lv, C.; Li, Y.; Yang, J.; Yang, J.; Chen, P.; Wang, H.; Huang, J. Adsorption of Cu (II) and Zn (II) ions from aqueous solution by gel/PVA-modified super-paramagnetic iron oxide nanoparticles. Molecules 2018, 23, 2982. [CrossRef]

40. Zhou, P.; Deng, Y.; Lyu, B.; Zhang, R.; Zhang, H.; Ma, H.; Lyu, Y.; Wei, S. Rapidly-deposited polydopamine coating via high temperature and vigorous stirring: Formation, characterization and biofunctional evaluation. PLoS ONE 2014, 9, e113087. [CrossRef]

41. Zhao, W.; Huang, J.; Lv, C.; Hu, S.; Yao, S.; Mei, L.; Lei, Y. pH stabilization of lactic acid fermentation via the glutamate decarboxylation reaction: Simultaneous production of lactic acid and $\gamma$-aminobutyric acid. Process Biochem. 2015, 50, 1523-1527. [CrossRef]

42. Peng, H.; Zhang, X.; Huang, $\mathrm{K} . ; \mathrm{Xu}, \mathrm{H}$. Modification of $\mathrm{Fe}_{3} \mathrm{O}_{4}$ magnetic nanoparticles by L-dopa or dopamine as an enzyme support. J. Wuhan Univ. Technol. Mater. Sci. Ed. 2008, 23, 480-485. [CrossRef]

43. Zor, T.; Selinger, Z. Linearization of the bradford protein assay increases its sensitivity: Theoretical and experimental studies. Anal. Biochem. 1996, 236, 302-308. [CrossRef] [PubMed]

44. Lyu, C.; Liu, L.; Huang, J.; Zhao, W.; Hu, S.; Mei, L.; Yao, S. Biosynthesis of $\gamma$-aminobutyrate by engineered lactobacillus brevis cells immobilized in gellan gum gel beads. J. Biosci. Bioeng. 2019, 128, 123-128. [CrossRef] 